\title{
Music and Protest in the African American Literature Course
}

\section{RHONDA PETTIT}

Incorporating the study of music into a humanities course seems like a viable option for upperlevel and honors courses where students' analytical and synthesis-building skills are more advanced than that of your typical freshman or sophomore student. As an associate professor in an open-access, regional campus of the University of Cincinnati, I teach to student abilities ranging from those with GED's in need of remedial assistance and tutoring to those on academic scholarships. Our classes also include a combination of traditional and non-traditional students, offered in 10-week quarters. One of my assumptions is that all of my students, regardless of scholastic background or age, possess at least a general interest in music, but can they write about it in a substantive way, or analyze it in light of, in my case, literary texts? My experience teaching an African American literature course where music is one of the texts proves that they can. This class also reveals the kinds of learning tools needed to help them do so.

In the spring quarter of 2008, I taught a topics-in-literature course titled "African-American Protest Literature," and while the word music was not used in the title, it was very much a part of the course. I had taught African-American literature before without including music, using an historical approach and major texts from the first edition of the Norton Anthology of African American Literature (Gates and McKay, 1997). For the new course, using the second edition, I wanted students to investigate the relationship between African-American musical and written texts that give voice to protest - from moan to rage, from endurance to celebration, from vernacular to written to rap. I retained the historical organization but divided the course into four sub-topics, each requiring a short paper assignment, according to musical genres and period writings:

\author{
Spirituals: Antebellum Writing \\ Work Songs, Prison Songs, Ballads, \& Songs of Social Change: Reconstruction / \\ The New Negro
}

Blues, Jazz, and Gospel: The Harlem Renaissance

Rhythm \& Blues to Rap: Civil Rights to Black Arts \& Beyond

The Norton Anthology facilitates this approach; its editors deliberately included musical texts as part of the literary tradition of African American culture. The anthology provides a CD of songs, readings, and speeches, containing many recordings of the song lyrics provided in the text. Other recordings of their lyrics, as well as other songs in their genres are readily available elsewhere, either online, in music stores, or perhaps in your own music collection. With regard to the protest component of the course, Joycelyn K. Moody's comment in the Norton Guide to Instructors suggests, somewhat sadly, an open field: "Nearly all African American literature falls into the category of protest literature." (75) Many of the literary texts in the Norton Anthology directly refer to or allude to music or song, further facilitating text selections.

My assumptions about my students' musical knowledge, which turned out to be fairly accurate, guided my pedagogy for this course. Except for the few musicians in the room, most of my students listened to music and knew what they liked, but didn't know how music worked on even the simplest 
level, and could not begin to write about it. After discussing the syllabus and the terms of the course literature, protest, music - in the first class, I used the second class to introduce some basic concepts of musical analysis. A music student myself, I brought in my guitar to demonstrate the difference between the sound and mood of a major chord, and those of a minor chord. Since most of my students had not been aware of this basic sound difference, it was clear they would need guidance in responding, not to just the meaning of the lyrics, but to the music of the songs we would play and discuss in class. They needed to understand, on a basic level, how the music reinforces the meaning of the lyrics before they could seek correspondences between the songs and the literary texts.

I took two steps to address this. First, students were required to locate source material either about music generally or specific genres related to the course. Given that these sources could then be used in their papers, most students sought genre material. Second, I developed a two-page "Music Analysis Worksheet" for both their in-class and out-of-class analysis of lyrics and music. The purpose of the worksheet was two-fold: 1) to help students discover the connection between musical sounds and the protest-related subject matter of the lyrics, and 2) to help students develop a descriptive metaphor for the song they had heard. The worksheet was designed for rapid note-taking while listening to the song, and more reflective writing afterward, allowing students to respond on both an emotional and analytical level:

\section{Personal Response}

1. What emotion/s do you feel while listening to this song?

2. What events in your life, if any, does this song make you think about?

\section{Analytical Response}

1. Do the lyrics:

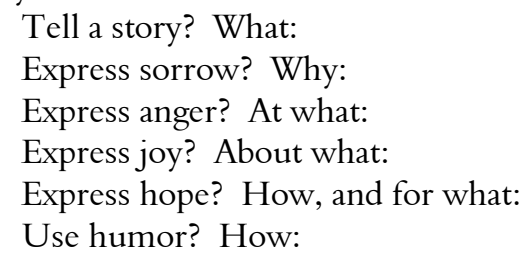

2. List any instruments, including voice, you hear in the song.

3. Think of the song in terms of its organization (beginning, middle, end; or stanza by stanza; or stanzas and refrain), and the relationship of the music to the lyrics. At what point is the music:

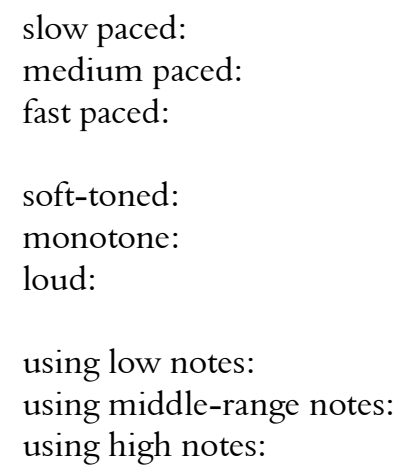

4. Select a moment in the music of this song that you find particularly powerful, moving, dull, or weak; or consider the song as a whole. If you were explaining this moment in the song, or the song overall, to someone who had never heard the song, what would you say it is like? Create a simile or metaphor to convey how this song works, and write it below. 
Students were introduced to the form and its purpose before using it. In keeping with Barbara Tewksbury's observation that students need to practice the application of concepts we teach in order to master them, the Music Analysis Worksheets were a repeated feature of the course. On average we devoted two to three class periods per sub-topic to the music. I selected one or two songs per sub-topic for class listening and analysis (students listened to the remaining songs on their own). We listened to each song twice, once for pure listening and a second time during which students filled out their Music Analysis Worksheet. After filling out the form in class, students shared their analyses in small groups and selected the best metaphors. Then as a class, we discussed their analyses and metaphors before moving on to the literary texts for that sub-topic. As a result of repeating this exercise, students began to pay attention to how the tempo, range, and tone of the music and/or voice related to the content of the lyrics, and this awareness, coupled with metaphors they developed, gave them substance for their papers. After group and/or class discussion of the literary text, we returned to the song (or songs to date) and sought correspondences between the music/lyrics and the literature. We considered the extent to which the songs, both lyrically and musically, used themes and imagery found in the literary texts or developed alternative approaches, reflected the context in which they were created, and gave voice to protest either directly or indirectly. Student papers for each sub-topic focused on these kinds of correspondences, found on their own in songs and literary texts they selected.

Initially I collected, read, and offered comments on the Music Analysis Worksheets, but as the course proceeded and students grew more confident in their listening and analytical skills, this was not necessary (they also turned in their worksheets with each paper). The most challenging aspect of the analysis for most students was developing the metaphor. Here the three-repeat strategy of worksheet, group discussion, and class discussion helped students meet this challenge. Also, students were required to incorporate some aspect of their worksheet material into each paper; this meant they had to return to what they had previously written, think critically about it, and use it as a source. For parts of each paper, then, the worksheet became a rough draft.

By using music as the primary organizing principle of the course, the historical approach to text selection offered some useful inconsistencies. For example, I used chapter XIV, "The Sorrow Songs," from W. E. B. Du Bois' The Souls of Black Folk in the Spirituals: Antebellum Writing portion of the course, even though it was published in 1903, during the later New Negro Period. This not only allowed students to consider literary history from a nonlinear perspective; it also gave students a model for music interpretation and analysis early in the course. Du Bois' interpretation of slave songs as the voice of protest reinforced the course's focus on music as a form of protest. The subversive nature of slave spirituals interpreted as a code for slave meetings and escapes raises the issue of figurative language, providing a pathway to analysis of not only the songs as literary texts, but the literature of the course as well.

As the course proceeded, students recognized how pounding rhythms replicate the content in work and prison songs like "Po' Lazarus," and then reoccur in poems like Sterling Brown's "Southern Road"; how jazz rhythms and twelve-bar blues structures are found in the poetry of Brown and Langston Hughes; how those forms tighten and repeat in Hip Hop and Black Arts Movement anger. Students learned to recognize the intersection of gender and race in the blues of Bessie Smith and songs like "You May Go but This Will Bring You Back" sung by Zora Neal Hurston. Our final project was to analyze the role of music in Spike Lee's explosive film, Do the Right Thing, giving them the added benefit of forging connections between music, words, and visual images. Part of their analysis was devoted to the development of their own definition of "protest literature."

While the assignments and activities described above involve fairly simple, perhaps obvious forms of musical analysis, these forms provide a good starting point for first- and second-year students. At the very least, the Musical Analysis Worksheet forces them to take note of the notes they listen to, and to identify the sound qualities associated with word meanings. This is a necessary first step to considering 
more complex interplays of music and language they could potentially encounter in upper level humanities courses, or in their lives as citizens in a world where combinations of language, image, and music are used rhetorically to sell products and concepts. Even as a one-time exposure to music in relation to other texts, a course using this worksheet helps students translate the music they hear into the written word, and hones and extends their interpretive and critical thinking skills.

\section{Works Cited}

Gates Jr., Henry Louis and Nellie Y. McKay, eds. The Norton Anthology of African American Literature, $2^{\text {nd }}$ ed. New York: Norton, 2004.

Moody, Joycelyn K. Teaching with The Norton Anthology of African American Literature: A Guide for Instructors, $2^{\text {nd }}$ ed. New York: Norton, 2004.

Tewksbury, Barbara J. "Defining Effective and Innovative Courses: A Practical Strategy." Workshop, University of Cincinnati Center for the Enhancement of Teaching and Learning, 10 February 2007. 


\title{
Syllabus
}

\author{
Topics in Literature - 28-001-203-008 \\ African-American Protest Literature \\ UC Raymond Walters College \\ Spring 2008 - MWF 12-12:50 p.m. \\ Professor Rhonda Pettit, Ph.D.
}

\section{Office Hours and Location}

MWF 1- 2 p.m., M 5-6, or by appointment, SAHB 132. Office Phone: 745-8319, or e-mail: rhonda.pettit@uc.edu

\section{Required Texts}

Gates \& McKay, eds., The Norton Anthology of African American Literature, $2^{\text {nd }}$ ed.

Dictionary and writing handbook or style guide

Completion of Freshman English I, II, and III.

\section{Course Pre-Requisites}

\section{Attendance Policy}

If you miss more than 4 classes, regardless of reason, your course grade will drop one letter. If you miss more than 6 classes, you will fail the course.

\section{Course Overview}

Literature broadly defined includes many kinds of written, discipline-specific texts, such as artistic or literary writing, scientific articles and books, medical articles and books, musical compositions and scholarship, etc. Protest literature broadly defined is any kind of writing that argues strongly against a perceived injustice or a forced inadequacy; it may criticize, demand change, or express anger. Our Norton Anthology editors state that most of the African American literature included in their volume - a substantial portion of which is music - is a form of protest literature, either directly stated or implied. This course will investigate the relationship between African American music and writing that give voice to protest - from moan to rage, from endurance to celebration.

We will approach this topic by reading and discussing a selection of songs, poetry, prose, drama, and film to determine the targets of African American dissatisfaction, and to understand how assumptions about race can tear the social fabric among and within groups. Related themes include religion, assimilation, gender, and art; and notice how many of our literary readings use or are about music. Our readings will be organized historically by song genre, taking us from the antebellum period to the contemporary period. But we will also move around within periods to see how later authors have written about the past that, in part, defined them. The course schedule below will give you a clearer picture of how we will proceed. Two additional assignments related to the college's celebration of National Poetry Month are also required.

Bring your syllabus to class every day. Adjustments to it may be made in keeping with the needs of the class. Read all assigned selections for the day before coming to class. Listening to the songs in advance is optional. I have not assigned the introductions to authors, songs, and periods in the anthology, but I recommend you read them. Your initiative will pay off in better papers and class participation. 


\section{Course Assignments}

In-class Assignments $\mathbf{- 2 0 \%}$. This category includes attendance, class participation, group work, and your Poetry Booth work at the Diversity Fair, as well as in-class writing assignments related to your four papers.

Four Papers - 15\% each (60\%). Our course is divided by song genre into four sections, and for each section, you will write a short paper in which you explore and explain any connections you can make between one of the songs and one of the texts from the time period, with an emphasis on how they both function as protest literature. In addition to discussing the course readings, we will devote class time to listening to songs, writing brief analytical and descriptive responses to the songs (lyrics and music, as well as performance), discussing these in groups, and discussing these as a class. You will select both the song and the literary text you want to write about, but they must come from the songs we listen to in class, and the literary works we read/discuss in class, or others included in the Norton Anthology.

An outside source is required for each paper (see April 9 listing on the Course Schedule below). Each paper should be 3 pages, typed, double-spaced, and use MLA style for in-text quotations and works cited material. Staple your relevant inclass writing and outside source to each paper.

Favorite Poem / Poetry Wall Project $\mathbf{- 1 0 \%}$. RWC is again this year sponsoring a Favorite Poem Poetry Wall to celebrate National Poetry Month in April. You will participate by selecting a favorite poem - one that has special meaning for you, or one that you fondly or problematically remember. It might be a nursery rhyme you heard as a child, a Robert Frost poem you read in high school, or a poem you read yesterday. No song lyrics, no poems written by you (submit those to our Poetry Writing Contest!), and no "Footprints" poems. Type your poem in 12 or 14 pt., and include the author and title of the poem. On the same page if possible, type a brief paragraph explaining why this is your favorite poem. Sign or type your name. Due Monday, April 14 or earlier.

Poetry Reading Response Paper $\mathbf{- 1 0 \%}$. You must attend the Pauletta Hansel poetry reading at the RWC Poetry Café (4/28, 6-9 p.m., SAHB 100), and write a 3-page (typed, double-spaced) response paper in which you describe the event, discuss at least 3 poems, and reflect on your experience. What were your expectations? What did you like, dislike, understand, or feel confused about? Was the reading overall and/or the poetry what you expected? What about the music? Were you surprised or disappointed? We will read and discuss a model paper to help you get started. Due May 12. 


\section{Course Schedule}

3/31 M Syllabus; Introduction: What is protest literature? How does musicwork?

\section{Spirituals and Antebellum Writing}

Songs: "Ezekiel Saw de Wheel" 11-12, "Go Down, Moses" 12, "Swing Low, Sweet Chariot" 14, "Steal Away to Jesus" 14

4/2 W Phillis Wheatley, "On Being Brought from Africa to America"219-220; Paul Laurence Dunbar, "An Ante-bellum Sermon" 912-914 (via Herbert Martin)

4/4 F James Whitfield, "Yes! Strike That Sounding String" 487-488

4/7 M W. E. B. DuBois, "The Sorrow Songs" 758-766

4/9 W Research Day: Use this class period to locate articles or books about music generally, and/or our specific genres, that you can use as sources for your four papers. If you use online articles, make sure you print the article, and have all the information you need for an MLA citation. Have your writing handbook with you, open to online citation examples, as you search for articles. Clip your articles together, put your name on them, and bring them to class on Friday. I will collect them for class work credit, and return them to you.

4/11 F Frederick Douglass, "What to the Slave Is the Fourth of July" 462-473

Research articles due Paper topic (song and writing) due

\section{Work Songs, Prison Songs, Ballads, \& Songs of Social Change and Reconstruction / The New Negro}

Songs: "You May Go but This Will Bring You Back" 30-31, "John Henry" 31-34, "Stackolee" 38-39, "Pick a Bale of Cotton" 41, "Go Down, Old Hannah" 42, "Strange Fruit" 45, "We Shall Overcome" 45-46; also look at Sterling Brown's "Southern Road" 1251-1252 and "Strong Men" 1252-1254

4/14 M Booker T. Washington, "The Atlanta Exposition Address" 594-602 1st Paper Questions?

4/16 W W. E. B. Dubois, "Criteria of Negro Art" 777-784

$1^{\text {st }}$ Paper Due

4/18 F NO CLASS: Attend, if possible the performance of Shakespeare's Julius Caesar, 10 a.m. to noon, Muntz Auditorium

4/21 M W. E. B. DuBois, "The Song of the Smoke" 691-692

4/23 W James Weldon Johnson, "Lift Ev'ry Voice and Sing” 794

4/25 F Paul Laurence Dunbar, "We Wear the Mask" 918 and "The Poet" 927

$2^{\text {nd }}$ Paper Topic Due 


\section{Blues, Jazz, \& Gospel: the Harlem Renaissance}

Songs: “C. C. Ryder” 51, "Rock Me Baby” 55, "It Don’t Mean a Thing” 66, "What Did I Do . ." 67, “This Little Light of Mine" 21; also look at Ralph Ellison's definition of the blues in "Richard Wright's Blues” on page 1539, first full paragraph.

4/28 M James Schuyler, “The Negro Art Hokum” 1221-1223

$2^{\text {nd }}$ Paper Questons?

Attend the Poetry Café, SAHB 100, 6-9 p.m.

4/30 W Meet at the Magic Magnets Poetry Booth at the Diversity Fair $2^{\text {nd }}$ Paper Due

5/2 F Langston Hughes, "The Negro Artist and the Racial Mountain" 1311-1314, plus any of his "song" poems

5/5 M Zora Neal Hurston, "How It Feels to Be Colored Me” 1030-1033; Marita Bonner, "On Being Young a Woman - and Colored" 1244-1247

5/7 W Writing Day: Use this and the next class period to write your Poetry Café response paper, and prepare for your next paper.

5/9 F Writing Day, continued. We will not meet as a class.

\section{Rhythm \& Blues to Rap: Civil Rights to Black Arts \& Beyond}

Songs: "A Change Is Gonna Come" 71, "Dancin' in the Street” 73, "Respect" 74, "What's Goin' On" 75, "The Message" 82, "The Evil That Men Do" 88

5/12 M Lorraine Hansberry, A Raisin in the Sun 1771-1830

$3^{\text {rd }}$ Paper Topic Due; Questions?

$5 / 14 \mathrm{~W}$

A Raisin in the Sun

$3^{\text {rd }}$ Paper Due

$5 / 16 \mathrm{~F}$

A Raisin in the Sun

$5 / 19 \mathrm{M}$

A Raisin in the Sun

$5 / 21 \mathrm{~W}$

James Baldwin, “Sonny’s Blues” 1728-1749

$5 / 23 \mathrm{~F}$

"Sonny’s Blues"

NO CLASS - Memorial Day Holiday

$5 / 28 \mathrm{~W}$

Larry Neal, “The Black Arts Movement” Section 1, 2039-2042

$5 / 30 \mathrm{~F}$

Audre Lorde, "Poetry Is Not a Luxury" 1924-1926; Mari Evans, "Status Symbol" and "I Am a Black Woman" 1851-1852; Amiri Baraka, "SOS” 1942, "Wailers" 1945-1946 \& on CD

$6 / 2 \mathrm{M}$

Spike Lee, Do the Right Thing (film)

$6 / 4 \mathrm{~W}$

Do the Right Thing 
$6 / 6 \mathrm{~F}$

$6 / 9 \mathrm{M}$
Do the Right Thing; wrap up; course evaluations

$4^{\text {th }}$ Paper Topic Due; Questions?

4th Paper Due by Noon, 132 SAHB

\section{Other Essential Information \& Policies}

\section{General Education Credit}

- This course fulfills the General Education Breadth of Knowledge (BoK) area of fine arts, and promotes the development of critical thinking and effective communication, two of the Baccalaureate Competencies.

\section{Other Course Policies}

- Think for yourself; cheat for no one. Review the university's plagiarism policy in the student handbook. Passing off someone else's writing or ideas as your own is plagiarism, a serious academic offence that will be dealt with seriously. Learn to cite your sources correctly using MLA style. See me if you have any questions.

- Turn off cell phones \& beepers \& other techy toys before entering class. No phone calls or text messaging allowed during the class period.

- Children cannot attend class (this is a college policy).

- Late assignments will be penalized, but I will grant deadline extensions to those who wish to take a draft to the Writing Center, provided you work this out with me in advance.

- Revisions to final papers are not allowed. However, I reserve the right to make exceptions to this rule on a case by case basis.

- Please respect the right of others to express an opinion.

- Violent behavior in the classroom will be reported to the Campus Police, department chair, and college deans, and may result in your expulsion.

- Please consider me as one of your resources; don't be afraid to ask questions.

\section{Learning Assistance}

- If you have any special needs related to your participation in this course, including identified visual impairment, hearing impairment, physical impairment, communication disorder, and/or specific learning disability that may influence your performance in this course, you should meet with me to arrange for reasonable provisions to ensure an equitable opportunity to meet all the requirements of this course. At the discretion of the instructor, some accommodations may require prior approval by Disability Services.

- RWC provides on-campus assistance for study skills development and writing tutorials. Contact: Study Skills (745-5730); or the Writing Center (745-5733). 


\begin{abstract}
"Music and Protest in the African American Literature Course" demonstrates how music can be used in a literature course designed for first- and second-year students who are not music majors, and have not yet developed the advanced analytical and synthesis-building skills of third- and fourth-year students. It offers pedagogical practices designed to address these students' needs, among them a Music Analysis Worksheet that allows them to respond both personally and analytically to the music they hear, and to develop metaphors for what they hear. The worksheet is general enough to be used in other courses or disciplines that include music in their course design.
\end{abstract}

